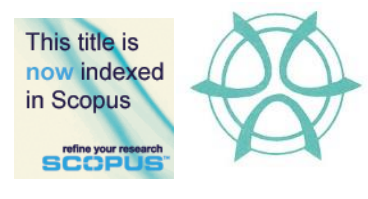

PLANNING MALAYSIA:

Journal of the Malaysian Institute of Planners

VOLUME XIV (2016), Page 15 - 28

\title{
UNDERSTANDING LAND IDLING AS A STRATEGIC BEHAVIOUR: A BRIEF NOTE USING THE REAL OPTIONS APPROACH
}

\author{
Haniza Khalid ${ }^{1}$ \\ ${ }^{1}$ Kulliyyah of Economics and Management Sciences \\ INTERNATIONAL ISLAMIC UNIVERSITY MALAYSIA
}

\begin{abstract}
One possible explanation for land idling in a rapidly transforming economy can be found by looking at the value of the option to wait and hysteresis behaviour in the land market. If investors assume that the drop is temporary and that its long term prospects outweigh current holding losses, the market will observe some form of a zone of inactivity i.e., no selling and no additional buying. The fact that landowners elect to keep their valuable land underdeveloped for prolonged periods of time suggests that idled land is more flexible and valuable than what the current market price suggests. If the revenue from farming is insufficient to sustain the activity, land is left idle; although this operational decision is open to continuous revision. The numerical example shown in the paper shows that price of land can be substantially bolstered by the option to wait embedded in land. We argue that land market prices are based on more than the land's total present value of its future income stream. In a transforming economy, the option to wait and change land-use are especially important to consider. Policy-wise, the government can discourage land idling by ensuring appropriate and suitable zoning of agricultural areas, strong adherence to the zoning conditions/plans as well as more far-sighted land conversion decisions. These efforts can go a long way to reduce the source and degree of uncertainty which is the most important cause of real option premium in land prices. Based on the nature and type of data available, future directions of research should emphasize on empirical testing of real options premium in sale prices of agricultural land.
\end{abstract}

Keywords: agricultural land prices, real options. asset pricing, opportunistic behaviour 
Haniza Khalid

Understanding Land Idling as a Strategic Behaviour: A Brief Note Using the Real Options Approach

\section{INTRODUCTION}

Today, land idling remains a major concern for Malaysia as the country attempts to reform its dwindling agricultural sector, enhance food production capabilities and improve farmers' income. The issue came to a head when a land survey carried out in 1981 by a special task force assembled the Ministry of Agriculture revealed that there are approximately 890,000 hectares of abandoned agricultural land, equivalent to roughly 20 per cent of all agricultural land in Peninsular Malaysia. Of that amount, $18 \%$ was paddy land (Sahak, 1986). In fact, more radical figures have been quoted about the real extent of the land abandonment in Malaysia. In an article published in 1995, the Director-General of Forest Research Institute of Malaysia estimated that 3 million hectares of farmland are not effectively cultivated (New Straits Times, 3 January 1995). A decade later, the 9th Malaysia Plan (Government of Malaysia, 2006, p.85) reports that 163,000 hectares are idled between the period of 2001 to 2005. In the 10th Malaysia plan, no official statistics were given but the government stated that it is acutely aware of the scarcity of suitable farmland for food production yet no new paddygrowing area is to be opened (Government of Malaysia, 2011, p. 137). The most recent data on idle agricultural land compiled by the Department of Agriculture is for 2014, where the total recorded acreage is 119,273 hectares; a land mass that is only slightly smaller than the state of Malacca.

Table 1 Number of Lots and Total Hectarage of Idle Agricultural Land in 2014

\begin{tabular}{llll}
\hline State & Number of Lots & Hectarage & $\begin{array}{c}\text { Percentage of } \\
\text { Agricultural land }\end{array}$ \\
\hline Perlis & 55 & 54.51 & \\
\hline Kedah & 3,065 & $5,518.98$ & \\
\hline Penang & 267 & 419.30 \\
\hline Perak & 5,214 & $14,506.92$ \\
\hline Selangor & 3,030 & $9,395.05$ \\
\hline Negeri Sembilan & 6,404 & $10,309.14$ \\
\hline Melaka & 2,568 & $3,629.97$ \\
\hline Johor & 8,070 & $17,854.93$ \\
\hline Pahang & 19,510 & $34,293.27$ \\
\hline Trengganu & 11,604 & $12,309.22$ \\
\hline Kelantan & 8,663 & $8,907.04$ \\
\hline Federal Territory of Labuan & 1,284 & $2,75.04$ \\
\hline Total & $\mathbf{6 9 , 7 3 4}$ & $\mathbf{1 1 9 , 2 7 3 . 0 4}$ \\
\hline Source: Department of Agriculture, Ministry of Agriculture Malaysia
\end{tabular}

Within the Malaysian National Land Code, abandoned agricultural land is defined as agricultural land which has been alienated to a private individual or firm but not cultivated after three years, or alienated agricultural land with suitable infrastructure for double-cropping (if paddy land) but is only cultivated once a year (National Land Code 1965 (Malaysia)). Causes of farm abandonment 
PLANNING MALAYSIA

Journal of the Malaysian Institute of Planners (2016)

can be broadly categorised into physical, economic and institutional factors. In locations where development pressures are intense, e.g. at the urban fringe areas, poor-yielding farms are even more vulnerable to land idling. Elsewhere, farmers may be vulnerable to poor climate conditions and price fluctuations as well low profit due to middle-men's exploitation. Other issues unveiled in studies by Mamat (1986), Buang (2001) and Manaf (2007) include out-migration of farm labour, capital limitations for farm renewal and increasing costs of production. There are also formal constraints inflicted on active land utilization such as gazetting specific farmland areas into state parks such as in the case of Mersing, Johor (Omar et al., 2011, Manaf, Hussain, Saad, and Mokhtarroji, 2012) as well as general depopulation trends in the rural areas. For a large number of inherited agricultural plots, the issue has been mainly the lack of consensus about distribution and compensation to the heirs/beneficiaries for the use or sale of the land.

One may ask, if there are indeed physical and economic challenges in operating the land profitably, then why not sell the land to a much stronger (financially and technologically) bidder? Why leave the land idle for seemingly infinite number of years? Many studies have been made about landowner's inertia in the market. Buang (2001) found that the Malays, who make up the largest group of landowners concerned, are generally reluctant to sell or lease the land to private developers, whom they view as outsiders. For historical and political reasons, owning and keeping the land in the family is far more important than earning income from it. Another possible explanation is because of the scarcity of assets that Malay rural households typically own. If land is the only major asset of value, by selling the land at its current intrinsic price, the household appears to be throwing away their wealth deposit when there is close to zero realistic chance of acquiring a similarly important asset again.

However today, the younger generation are not as keenly opposed to selling their family land assets as their forefathers were, since many have now gained income from non-agricultural activities or have migrated to the cities. Their reluctance to sell could be because they are holding out for better prices, which, in a sense, is a form of strategic behaviour. Furthermore, if the prevailing development rate persists and spreads to the rural area, landowners learn to expect that market price for land will pick up eventually, despite whatever current returns from land activities. The result of this form of behaviour is that there would be some inertia in disposing the land.

Using an options-based framework, which has its origin in the corporate finance discipline, we can offer some explanation about this unique land ownership behaviour in which individuals or firms hold up land stocks for future use, despite zero current returns. The land may be unutilized or underutilized while the owner's wait for more information about land's future worth or while waiting for a higher bid price for the land to emerge. However, how much of a 
Haniza Khalid

Understanding Land Idling as a Strategic Behaviour: A Brief Note Using the Real Options Approach

premium is considered enough? Is there a threshold price where the seller will know that this the time to sell and the buyer, the time to buy? An astute investor/speculator builds strategic agricultural land stock by either buying directly from private individual landowners or by acquiring another agricultural firm with substantial land assets. Of course, it can be suggested that the behaviour is a natural extension of a firm's hedging strategy. For instance, a rubber plantation firm stocks up on additional rubber land when the commodity market for rubber is particularly weak. This opportunistic behaviour ensures that the firm has a head start in delivering greater market supply when prices are restored to better levels, compared to firms which had failed to strategize in that respect. However, the real options (RO) theory actually goes a step further, by incorporating the possibility or a total and irreversible land-use change into the price of the land. Agricultural land is essentially sought after for its future development multi-potential (e.g. real estate, highways, mineral exploration, high-technology industrial plants, commercial complexes and so forth), a notion consistent with what Berry (1978) describes as the 'impermanence syndrome' with respect to land-use. The value of this flexibility is inevitably capitalised in its price and it follows that the more fluid the conditions in the economy (through rapid economic growth and/or through the gradual relaxation of land-use controls), the greater the value of this flexibility. It can be argued that uncertainty in future returns on land lead to the difference between the conventional present value of land in its current use and its actual sales value. Here lies the major advantage of using the Real Options theory over the classic Net Present Value (NPV) formula, especially for a rapidly transforming economy such as Malaysia. RO is entirely able to incorporate systematically and clearly the concept of opportunistic purchasing behaviour encouraged by uncertainties in the economy, whereas the NPV approach does not. Consequently, it is possible to separate the intrinsic value of the land's present contribution and the premium derived from its flexibility in future use.

In an RO framework, the acquisition of an undeveloped land grants the buyer a right, but not an obligation, to make follow-on investments to maximise potential returns from its use in the future. In short, agricultural land essentially represents an option to profit from investments in its highest and best potential use. If market prospects later turn out to be not as promising as it was thought to be, the landowner has the option to defer the follow-on investments. The RO theory also recognises abandonment of a project as a viable alternative that is actually contemplated at the outset. Williams (1991) states if the costs of carrying an undeveloped property exceed its operating revenues, the landowner has the option to dispose the asset. However, there are exceptional circumstances in which disposal may not occur. According to Turvey (2002), this could be a special case of RO pertaining to a behavioural characteristic called hysteresis. If the landowner believes that falling output prices is merely temporary, and that the 
PLANNING MALAYSIA

Journal of the Malaysian Institute of Planners (2016)

land's long term prospects outweigh current holding costs, they might hesitate to dispose the land hastily. On aggregate, the market may enter a zone of inactivity i.e., no selling and no additional buying.

The primary purpose of this paper is to offer an explanation about the 'rationale' behind inactivity or land idling using the Real Options framework. Most studies with respect to idle land in Malaysia employ landowners' survey data of specific communities or locations to understand the key factors leading to land abandonment. However, there has not been any study, to the best of our knowledge, that adopted a more rigorous or full-fledged econometrics treatment, either in a hedonic price model, a contingency valuation model or a long-run causality model for a larger and more comprehensive set of data for the whole country. This is understandable with the given constraints of putting together a reliable dataset for land in Malaysia; although work is progressing in that direction. However, given the attractiveness of the RO theory for understanding the abandoned agricultural land issue, we took the initiative to first advance a theoretical description of how the three types of options introduced above can be embedded in a landowner's offer or reservation price for a parcel of land. It should subsequently lead to some clues as to why land idling remains an enduring characteristic of the Malaysian land market and what can be instituted to resolve the problem.

The paper is organized as follows. In the RO theoretical section, we describe the conceptual framework that underlies causes for hysteresis in landowner's market behaviour. In the numerical example section, we present a binomial decision-making model to show the potential extent of option to wait premium enjoyed by a landowner, and how land idling could end up being a 'rational' decision for the landowner. The final section concludes and provides some recommendations for solving the idle land problem and future research directions.

\section{REAL OPTIONS: A THEORETICAL OVERVIEW}

In finance, an option is a derivative whose value is dependent upon the value of another asset, called the underlying asset (e.g. stocks, bonds, commodities, currencies and indexes), as well as fluctuations in the value of the underlying asset. Option pricing theory was developed based on seminal papers by Black and Scholes (1973), Merton (1973), and Cox, Ross and Rubinstein (1979). It is basically a concept of pricing financial assets; eventually extended to pricing 'real' assets which exhibit option-like features, including land. The term "Real Options" (RO) was first discussed by Myers (1977) and has since been an important consideration in capital-budgeting decisions by firms. In summary, a real option represents the value to a firm of having the flexibility to accept, reject, or postpone making additional investment on the project. Certain investment 
Haniza Khalid

Understanding Land Idling as a Strategic Behaviour: A Brief Note Using the Real Options Approach

decisions made early in the timeline are to allow the firm to take more profitable opportunities that may come its way in the future, even if the precise nature of opportunities or benefits are not yet known at the time of sale (Pike \& Neale, 2003). The RO outlook encourages a 'wait and see' approach to a given investment and is valuable in the project design stage (Bowman \& Moskowitz, 2001). Put in another way, by choosing not to purchase the option, a firm will lose out on potentially higher profit-making opportunities that may emerge in the future.

A call option gives its holder the right to purchase an underlying asset (share of a stock, index, interest rates) at a certain exercise price upon or before a specific date. Basically, the value of a option is nil if uncertainty is fairly limited but will be high if uncertainty is also high i.e. the return is unpredictable and possibly quite large. Today the options approach is widely applied on real assets to analyse corporate investment decisions which are undertaken in stages i.e. spread out over a period of time upon reaching certain minimum optimal conditions or 'hurdles' for each stage. Examples include decisions relating to acquisition of land for development, purchase of rights on internet innovations, license for oil exploration and brand names. A strategic asset is considered a call option because it gives its holder the right to stake his claim or make a transaction on another asset, which is called the underlying asset; by paying a specified exercise price, on or before an expiration date.

There are several important characteristics of land that lends itself well to the RO hysteresis theory. Firstly, land ownership essentially represents an investment which creates opportunities to make even larger investments (and therefore a substantial amount of profit) in the future. Money paid to purchase a parcel of land is payment made to acquire the call option on an underlying asset. On the other hand, the underlying asset can be almost anything: real estate, industrial plant, commercial complex, agricultural project and so forth. Note that it is the potential profit from the underlying asset that motivates the land purchase in the first place. Hence, land is essentially the call option here.

Secondly, investment in land typically involves large sunk costs and a high degree of asset specificity, such that reversing the investment would be costly, if not impossible. For instance, residential development on agricultural land is considered irreversible because of the high cost involved and the long period needed to rehabilitate and prepare the land for agriculture again. Hence, in the case of land which does not have a perceivable expiry date, it would make sense for the landowner to wait for the best time to move to the subsequent stage of investment. In finance, this is called exercising the option.

Thirdly, the amount of profit to be made from any completed land development project is subject to various sources of market and non-market uncertainties, hence it cannot be accurately determined at the time of the land purchase. In an option-based framework, the greater the uncertainty about final 
PLANNING MALAYSIA

Journal of the Malaysian Institute of Planners (2016)

profit, the higher the value of the option embedded in the asset. This is because larger uncertainties increase the potential positive payoffs from the option, while potential loss is kept minimal (since land can always be re-sold and its value can never drop to zero).

Finally, uncertainty tends have an adverse effect on investment levels on land; firms wait for better signals from the market and invest conservatively in the meantime. Landowners hold on to the land in spite very poor or negative farming income (due to land idling) simply to preserve the option to make greater profits from land's underlying asset later.

By now, it is easy to see that in RO framework, buying land is not merely about buying cheap and selling high, which might be the basic game plan of a true land speculator. In RO framework, there is actually an underlying asset to be realised and purchase of land is a pre-condition for that to happen. The fact that landowners elect to keep their valuable land vacant or underdeveloped for prolonged periods of time suggests that vacant land is more flexible and valuable than what the current market price suggests (see for example, Yamazaki, 2001). Landowners stand to gain by "keeping the option alive" as long as they can, unless and until personal financial circumstances or the land authorities coerce them to utilise the land or transfer it to other agents. In short, landowners who view future uncertainties with an RO perspective tend to delay the supply of land to the market. If the revenue from farming is insufficient to cover costs, land is left idle; although this operational decision is open to continuous revision from time to time.

In summary, land idling (where there is no government subsidy or compensation involved) may be a result of hysteresis similar to the phenomenon often observed in financial markets. If landowners believe that land prices will eventually turn around at some point soon, they will increase their reservation offer prices. As this behaviour spreads, supply of land to the market will shrink so much that it will push prices upwards. This tends to happen even when there are no signals indicating that the land's income or productivity will become better. Ultimately, the belief that land prices will move upwards becomes a selffulfilling prophecy (Turvey, 2002; Maart-Noelck \& Musshoff, 2011; Musshoff, Odening \& Schade, 2012). Marginal cost of farming can be viewed as the strike price on an option to farm. Therefore, when marginal returns from farming fall below marginal costs, farming activities will naturally cease. Under the capital asset pricing rule, an asset with negative cash flows is considered worthless. Yet the hysteresis behaviour dictates that the price would remain high. In any case, an option value is always affixed to whatever the present value of land's income and its expected growth potential. 
Haniza Khalid

Understanding Land Idling as a Strategic Behaviour: A Brief Note Using the Real Options Approach

\section{NUMERICAL ANALYSIS}

Say that a parcel of agricultural land is perceived suitable for residential development. Hence, the underlying asset value is the final value of completed residential properties, $\mathrm{V}$. The exercise price here is the cost of constructing the property, I. The payoff or profit to the investor would be the difference between the price of the underlying asset and the option's exercise price or (V - I). The time to the option's expiration, $\mathrm{T}$, can be specified as the time by which the option holder must proceed with construction or let the option lapse. It is possible to find $\mathrm{T}$ if the planning permission approval document, as an option agreement for example, specifies the approval's expiry period. Otherwise, it can be assumed that $\mathrm{T}=\infty$.

In the classic financial option-pricing model, an underlying asset is assumed tradable (e.g. Stocks, bonds or indexes). Therefore, it is possible to construct a hedged portfolio that can eliminate almost all investment risks (Ross, 1976; Cox et al., 1979). This can be done by maintaining a long position in the asset and a short position in the option. A long position in the asset means that the investor buys a security with the expectation that the asset will rise in value, whereas a short position in the option entitles the investor the right (not the obligation) to sell the asset to the market at a specified price. The overall effect is that the investor is able to do away with investment risks by purchasing an option to hedge his investment against a price decline.

With respect to real assets, risks in an investment project are hedged away by dynamically trading a perfectly correlated single asset or an equivalent portfolio of marketed assets that share the same payoff probability and risks as the land project. The existence of this "twin asset" allows the investor to calculate the fair value that would prevail if the land project was indeed 'tradable' in the market. Because of the perfect hedging possibilities, investors in the RO framework can adopt a 'risk-neutral valuation' of expected future payoffs from an investment. The rate of interest is selected by referring to the "twin asset" to provide essential market information about investment risks and returns (see Dixit, 1991; Dixit \& Pindyck, 1995).

To illustrate, assume that there are only two state variables. Each year, the value of the residential project which is the underlying asset, $V$, either goes up as $\mathrm{Vu}$ or down as $\mathrm{Vd}$ according to a given percentage with a probability ratio, p. Shown below is a decision tree indicating the project's values, V, with the two possible paths that V could take at one time interval (see Trigeorgis, 1996). The risk-free interest rate is also assumed constant, and individuals may borrow or lend as much as they wish at this rate. In this one-period analysis, the gross value of the completed land project, $\mathrm{V}$, and the price of its twin asset, $\mathrm{S}$, move over the next period, as follows: 
PLANNING MALAYSIA

Journal of the Malaysian Institute of Planners (2016)
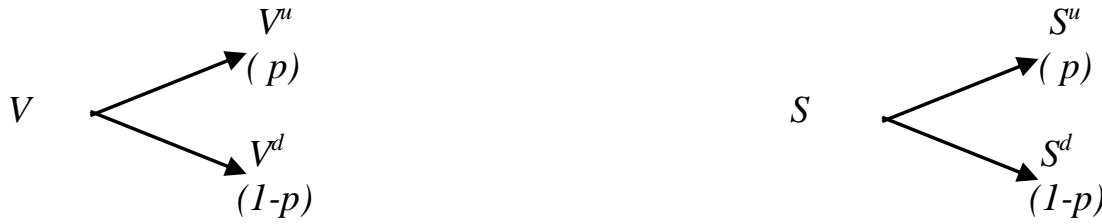

In the traditional present value formula, the present value of the project, $V_{0}$, is dependent on the actual probability, $p$, and the expected risk-adjusted rate of return $k$. Since the outcome is uncertain, $V_{0}$, can be expressed as follows,

$$
\begin{aligned}
V_{0} & =E\left(V_{1}\right) /(1+k) \\
& =\frac{\left[p V^{u+}+(1-p) V^{d}\right]}{(1+k)}
\end{aligned}
$$

(Eq.

1)

The value of a call option, denoted as $C$, moves in a manner that is positively correlated with the movements in its underlying asset, $V$ or its twin, $S$. The higher the value of final asset and its twin, the higher is the value of the option. Instead of actual probability, the approach uses risk-neutral probabilities, $p^{\prime}$, i.e., the probability that the expected value of returns, discounted today at a risk-free interest rate equals the asset's current market value,

$$
p^{\prime}=\frac{\left[(1+r) S-S^{d}\right]}{\left(S^{u}-S^{d}\right)}
$$

(Eq.

2)

Having identified the main parameters in RO framework through this numerical analysis, we use the simple land development example earlier to show the computations of the option to wait embedded in undeveloped agricultural land. The option to defer can be reflected in the landowner's decision to withhold land from the market, cultivated or idled.

For simplicity, it shall be assumed that once the houses are constructed, all units will be sold and no follow-on investment is needed. The housing project has a realisable sales value, $V$, of say, either RM170K or RM60K, depending on the local market's prospects. If it is assumed that the market for houses are efficient, then the two outcomes have equal probability $(p=0.5)$. Let $S$ be the 
Haniza Khalid

Understanding Land Idling as a Strategic Behaviour: A Brief Note Using the Real Options Approach

listed stock price of an identical development project which plays the role of the 'twin asset'; and is assumed to have a spot price of RM15. The value of the twin asset can change to RM25.5K (an increase of 70\%) or to RM9K (a decrease of $40 \%$ ), depending on housing market's current profitability outlook. Finally, because both the project and its twin security are perfectly correlated, presumably they would share the same expected rate of return, $k$ and risk-free interest rate, $r$, which are assumed to be $15 \%$ and $4 \%$ respectively. To help find the project's present value at the beginning i.e., when the investment decision is being considered, $V_{0}$, the land development decision tree is presented as follows,

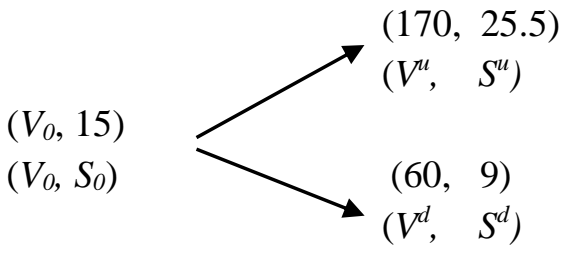

Because gross project value, $V$, is exactly proportional to the twin asset's price, $S$, the former also increases by 70 percent or fall by 40 percent for each period and with probability, $p=0.5$. Hence, the present value of the project's final asset, $V_{0}$, can be obtained via the standard NPV formula by working backwards following Eq. 1 above.

Substituting the relevant values of $p$ and $\mathrm{k}$ yields $V_{0}=\frac{[(0.5 \times 170)+(0.5 \times 60)]}{(1+0.15)}=100 \mathrm{~K}$

Whereas, in the RO formula, the riskneutral probability, $p^{\prime}$, is computed according to Eq. 2, where $p^{\prime}=[(1.04 \times 15)-9] /(25.5-9)=0.4$. Substituting the relevant values of risk-free interest rate, $r$ and risk-neutral probability, $p$ ' into Eq. 1 will yield

$$
V_{0}=\frac{[(0.4 \times 170)+(0.6 \times 60)]}{(1+0.04)}=100 \mathrm{~K} \text {. }
$$

Since an option is priced relative to the value of its underlying asset, $V$, the price of an option, $C_{0}$, can be expressed in a similar manner, 
PLANNING MALAYSIA

Journal of the Malaysian Institute of Planners (2016)

$$
C_{0}=\frac{\left[p^{\prime} C^{u}+\left(1-p^{\prime}\right) C^{d}\right]}{(1+r)}
$$

(Eq.

3)

Using this basic formulation, it is possible to evaluate the option to defer investment in an asset (Trigeorgis, 1996). To complete the parameters of the model, assume that the cost of construction computed at the beginning of the investment period, $I_{0}$, is RM105K. The value of an option to wait is the difference between the final asset's value and the exercise price, or zero, whichever is greater,

$$
\max \left(V-I_{0}, 0\right) .
$$

At the beginning of the investment, the expected future value of the construction cost at the end of Year 1 is $I_{1}=105(1+0.04)=109.2 \mathrm{~K}$. Say that local building laws require construction to commence within one year of the planning permission approval. To correspond to probabilities that final asset value, $V$, can go up or down, the probable option price, $C$, can be computed based on Eq. 3,

$$
\begin{aligned}
& C^{u}=\max \left(V^{u}-I_{1}, 0\right)=\max [170-109.2,0]=60.8 \mathrm{~K} \\
& C^{d}=\max \left(V^{d}-I_{1}, 0\right)=\max [60-109.2,0]=0
\end{aligned}
$$

Using the two possible option prices, the timing option's present value is found to be equivalent to

$$
C_{0}=\frac{\left[p^{\prime} E^{u}+\left(1-p^{\prime}\right) E^{d}\right]}{(1+r)}=\frac{[(0.4 \times 60.8)+(0.6 \times 0)]}{(1+0.04)}=23.38 \% \text { of the project's }
$$

present value, $V_{0}$, which was computed as RM100K earlier.

The example above shows that landowners stand to gain by "keeping the option alive" for as long as they can, unless and until personal financial circumstances or the law forces them to utilise or put the land on sale. In the example above option to wait is worth as much as 23 per cent of the value of the land. Whether or not the land is cultivated does not take anything away from the option-based price of the land. Basically landowners hold on to the land in spite very poor or negative farming income (due to land idling) simply to preserve the option to make greater profits from land's underlying asset at a future date. 
Haniza Khalid

Understanding Land Idling as a Strategic Behaviour: A Brief Note Using the Real Options Approach

\section{CONCLUSION}

Land is viewed as a call option on future outputs of the land either in development or agricultural use. Both landowners and prospective buyers are aware of the flexibility in land-use and assume optimistic positions with respect to future returns, particularly if there are (expected) continuous high rate of economic growth and a rather lax land-control environment. It follows that the more fluid the conditions in the economy, the greater the value of land's flexibility and hence this option to wait. We used a binomial decision tree to provide a numerical example of how the different parameters in $\mathrm{RO}$ work as well how the final RO pricing decision differs substantially from what a classic net present value calculation would produce. By assuming specific values for the parameters, our example showed that the option to wait value can constitute up to $23 \%$ of the sales price of the land. In general, with each land purchase decision lying before them, landowners can adopt values for probabilities and risks to the same decision tree analysis above when deciding on the offer or reservation price that he wants for his land.

To summarize, ownership of land grants its owner various type of options namely: to complete, to defer or to reject potential project (underlying asset) in the future. The option to defer coupled with hysteresis in the land market may be responsible for the 'zone of inactivity' i.e., no selling and no additional buying, even when the land's intrinsic value is close to zero. Understanding the significance of the option to wait and the ability to measure its magnitude in relation to price may give some clues why land idling is technically a rational solution for landowners. Subsequently, the findings imply that government efforts which do not recognise the value of the option might fail to induce landowners to sell their land rather than keeping the land idle. For planners in general, we hope to show in a technical manner, that land valuations and market values are based on more than the land's total present value of its future income stream. In an economy that is undergoing rapid transformation, the option to wait and change land-use statuses are extremely important to consider. Policy-wise, the government can discourage land idling by ensuring appropriate and suitable zoning of agricultural areas, strong adherence to the zoning conditions/plans as well as more far-sighted land conversion decisions. These efforts can go a long way to reduce the source and degree of uncertainty which is, as explained in the theoretical part, the single most important cause of real option premium in land prices. 


\section{REFERENCES}

Berry, D. (1978). Effects of urbanization on agricultural activities. Growth and Change, 9(3), 1-8.

Black, F. \& Scholes, M. (1973). The pricing of options and corporate liabilities. The Journal of Political Economy, 81, 637-654.

Bowman, E. H. \& Moskowitz, G. T. (2001). Real options analysis and strategic decision making. Organization Science, 12(6), 772-777.

Buang, A. (2001). Privatizing the rehabilitation of idle agriculture land in malaysia feedback from the Malay folks. Pertanika Journal of Social Sciences \& Humanities, 9(2), 103-112.

Cox, J. C., Ross, S. A., \& Rubinstein, M. (1979). Option pricing: A simplified approach. Journal of Financial Economics, 7(3). 229-263.

Dixit, A. (1991). Analytical approximations in models of hysteresis. Review of Economic Studies, 51(1), 141-51.

Dixit, A. K. \& Pindyck, R. S. (1995). The options approach to capital investment. Harvard Business Review, 73(3), 105-116.

Government of Malaysia (2006). Ninth Malaysia Plan, 2006-2010. Kuala Lumpur: National Printing Department.

Government of Malaysia (2011). Tenth Malaysia Plan, 2011-2015. Kuala Lumpur: National Printing Department.

Maart-Noelck, S. C. \& Musshoff, O. (2013). Investing today or tomorrow? An experimental approach to farmers' decision behaviour. Journal of Agricultural Economics, 64(2), 295-318.

Mamat, S. (1986). Memperdagangkan tanah sawah terbiar dalam konteks beberapa polisi kerajaan. Paper presented at National Rice Conference, 20-22 January, 1986, Serdang.

Manaf, A. A. (2007). Keupayaan pendekatan institusi dalam menghurai punca-punca tanah pertanian terbiar di daerah Kuala Pilah, Negeri Sembilan. Jurnal Sains Sosial dan Kemanusiaan, 2(2), 25.

Manaf, A. A., Hussain, M. Y., Saad, S. \& Mokhtarroji, N. K. (2012). Aplikasi pendekatan institusi ekonomi ke atas tanah pertanian terbiar di pulau-pulau sekitar Mersing, Johor Geografia: Malaysian Journal of Society and Space, 8(5), 14-25.

Merton, R. C. (1973). Theory of rational option pricing. Bell Journal of Economics and Management Science, 4, 141-183.

Musshoff, O., Odening, M., Schade, C., Maart-Noelck, S. C. \& Sandri, S. (2012). Inertia in disinvestment decisions: experimental evidence. European Review of Agricultural Economics, 40(3):463-485. doi: 10.1093/erae/jbs032.

Myers, S. C. (1977). Determinants of corporate borrowing. Journal of financial Economics, 5(2), 147-175.

National Land Code 1965 (Malaysia)

Omar, M., Radzi, M. M., Selamat, M. N., Manaf, A. A., Shamsudin, M. \& Saim, N. J. (2011). Faktor penentu dan implikasi fenomena depopulasi komuniti Pulau Kecil di sekitar Mersing. Journal of Tropical Marine Ecosystem, 1, 22-34.

Pike, R. H. \& Neale, B. (2003). Corporate Finance and Investment: Decisions and Strategies (Fourth Edition). Harlow: Prentice Hall. 
Haniza Khalid

Understanding Land Idling as a Strategic Behaviour: A Brief Note Using the Real Options Approach

Ross, S. A. (1976). Options and efficiency. The Quarterly Journal of Economics, 90(1), 75-89.

Trigeorgis, L. (1996). Real options: managerial flexibility and strategy in resource allocation. Cambridge: MIT Press.

Turvey, C. (2002). Can hysteresis and real options explain the farmland valuation puzzle? Department of Agricultural Economics and Business, University of Guelph.

Williams, J. T. (1991). Real estate development as an option. Journal of Real Estate Finance and Economics, 4(2), 191-208.

Yamazaki, R. (2001). Empirical testing of real option pricing models using Land Price Index in Japan. Journal of Property Investment \& Finance, 19(1), 53-72. 